The Common Agricultural Policy of the European Union the present and the future

EU Member States

point of view 



\section{INSTITUTE OF AGRICULTURAL AND FOOD ECONOMICS NATIONAL RESEARCH INSTITUTE}

\section{The Common Agricultural Policy of the European Union - the present and the future}

\section{EU Member States point of view}

Editors:

dr Marek Wigier

prof. dr hab. Andrzej Kowalski

Proceedings of the International Scientific Conference

"The Common Agricultural Policy of the European Union - the present and the future" Multi-Annual Programme 2015-2019

"The Polish and the EU agricultures 2020+. Challenges, chances, threats, proposals" 5-7 December 2017 Stare Jabłonki, Poland

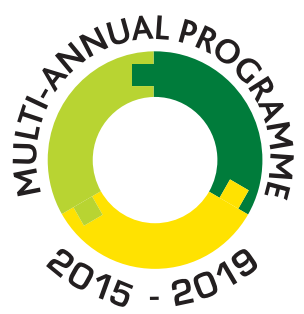

THE POLISH AND THE EU AGRICULTURES 2020+ CHALLENGES, CHANCES, THREATS, PROPOSALS

Warsaw 2018 
This monograph was prepared under the Multi-Annual Programme 2015-2019

"The Polish and the EU agricultures 2020+. Challenges, chances, threats, proposals".

The publication is a collection of selected papers delivered at the 22th edition of the International Scientific Conference organized by the Institute of Agricultural and Food Economics - National Research Institute. The theme of the conference was "The Common Agricultural Policy of the European Union the present and the future. The conference was placed on 5-7 December 2017 in Stary Jabłonki in Poland. Common Agricultural Policy was and still is one of the key pillars of European integration. Published in two volumes materials refer directly to the current and future of the CAP in EU and non EU member states, the strategic objectives and principles of agricultural policy for the agri-food sector and rural areas, address the issues of equilibrium between agriculture, forestry and land use, relate to the dilemmas for the EU budget and the CAP after 2020, CAP instruments and their adjustment, transformations of the rural economy and programming of the rural and agricultural policy, as well as productivity and production efficiency and tensions between sectoral action and between different models of territorial activities.

In the Scientific Committee of the Conference was participated: Prof. Andrzej Kowalski (IAFE-NRI, Poland), Prof. Drago Cvijanonivić (University of Kragujevac, Serbia), Prof. Thomas Doucha (IAEI, Czech Republic), Noureddin Driouech, PhD (CIHEAM, Italy), Prof. Szczepan Figiel (IAFE-NRI, Poland), Prof. Masahiko Gemma (Waseda University, Japan), Prof. Wojciech Józwiak (IAFE-NRI, Poland), Prof. Jacek Kulawik (IAFE-NRI, Poland), Prof. Yuriy Oleksiyovych Lupenko (IAE, Ukraina), Prof. Věra Majerová (CULS, Prague), Prof. Dimitre Nikolov (IAE, Bulgaria), Maire Nurmet, PhD (EMÜ, Estonia), Prof. Gabriel Popescu (ASE, Romania), Norbert Potori, PhD (AKI, Hungary), Prof. Włodzimierz Rembisz (IAFE-NRI, Poland), Piotr Szajner, PhD (IAFE-NRI, Poland), Prof. Alina Sikorska (IAFE-NRI, Poland), Prof. Jonel Subić (IAE, Serbia), Prof. Samuele Trestini (UNIPD, Italy), Prof. Olga Varchenko (Bila Tserkva National Agrarian University, Ukraine), Dipl.-Ing. Klaus Wagner (AWI, Austria), Marek Wigier, PhD (IAFE-NRI, Poland), Prof. Józef St. Zegar (IAFE-NRI, Poland)

In the Organising Committee of the Conference was participated: Małgorzata Bułkowska (IAFE-NRI, Poland), Anna Hankiewicz (IAFE-NRI, Poland), Joanna Jaroszewska (IAFE-NRI, Poland), Joanna Korczak (IAFE-NRI, Poland), Krzysztof Kossakowski (IAFE-NRI, Poland), Irena Mikiewicz (IAFE-NRI, Poland), Małgorzata Mikołajczyk (IAFE-NRI, Poland), Lech Parzuchowski (IAFE-NRI, Poland), Ewa Sierakowska (IAFE-NRI, Poland), Paulina Smakosz (IAFE-NRI, Poland), Leszek Ślipski (IAFE-NRI, Poland), Marek Wigier, PhD (IAFE-NRI, Poland).

Reviewers:

Professor Dimitre Nikolov, Institute of Agricultural Economics, Sofia, Bulgaria

Professor Gabriel Popescu, The Bucharest University of Economic Studies, Bucharest, Romania

Professor Samuele Trestini, University of Padva, Italy

Proofreader

Katarzyna Mikulska

Technical editors:

Joanna Jaroszewska, Barbara Pawtowska, Ewa Sierakowska, Kamila Tomaszewska,

Barbara Walkiewicz

Translated by

Summa Linguae S.A.

Cover Project

Leszek Ślipski

ISBN 978-83-7658-743-1

DOI: $10.30858 / \mathrm{pw} / 9788376587431$

Instytut Ekonomiki Rolnictwa i Gospodarki Żywnościowej

- Państwowy Instytut Badawczy

ul. Świętokrzyska 20, 00-002 Warszawa

tel.: (22) 5054444

faks: (22) 5054636

e-mail:dw@ierigz.waw.pl

http://www.ierigz.waw.pl 


\section{Contents}

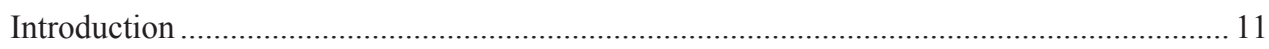

Dr Marek Wigier

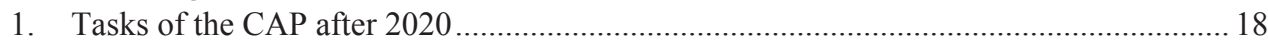

Dr hab. Julian Krzyżanowski

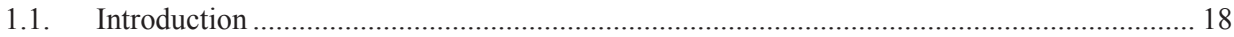

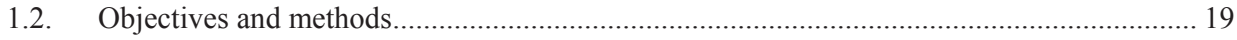

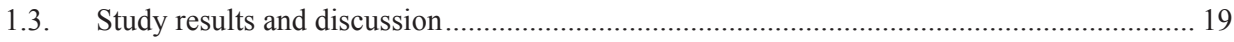

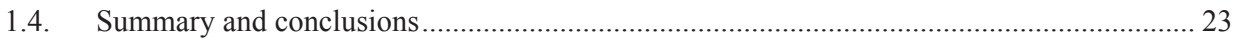

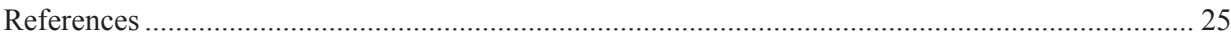

2. An assessment of the regional impacts of post-2020 CAP budgetary cuts on production

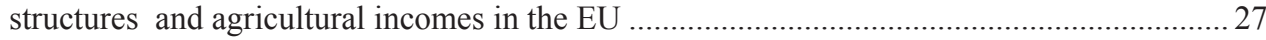

PhD Norbert Potori, PhD János Sávoly, PhD Szabolcs Biró

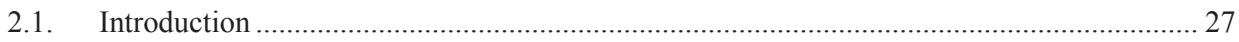

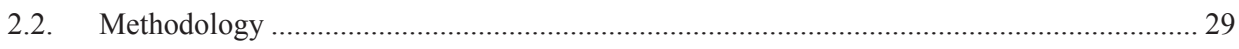

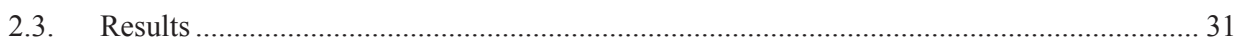

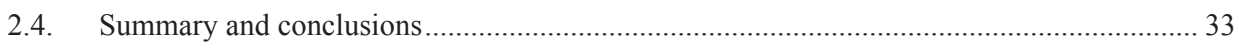

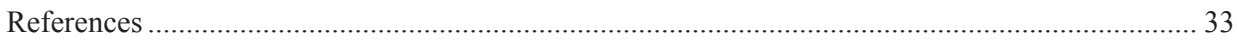

3. Is there room for financial instruments in the Common Agricultural Policy? Casus of

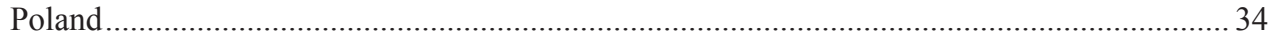

Prof. dr hab. Jacek Kulawik, PhD Barbara Wieliczko, PhD Michat Soliwoda

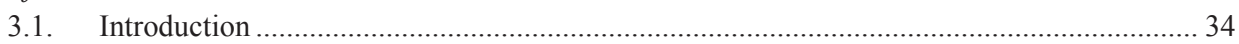

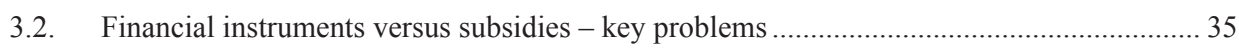

3.3. The use of financial instruments under the EU policy ......................................................... 37

3.4. Example of the use of FI in the 2014-2020 programming period ......................................... 38

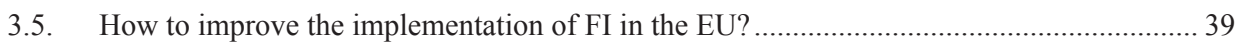

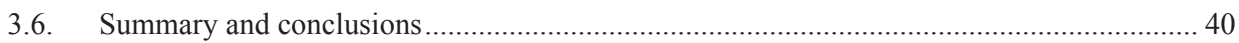

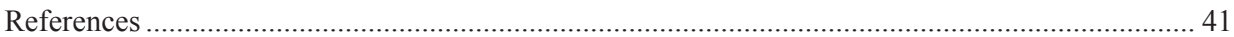

4. The past, present and future of the CAP - the Hungarian viewpoint ............................. 43

Dr Tamás Mizik

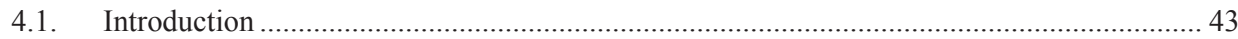

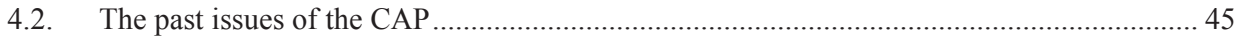

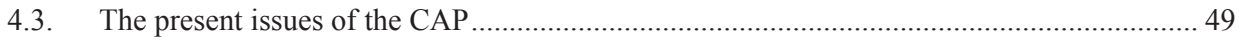

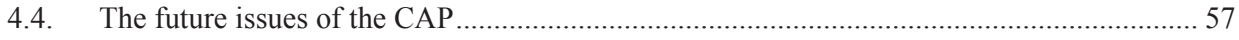

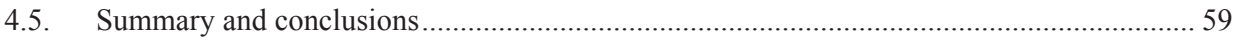

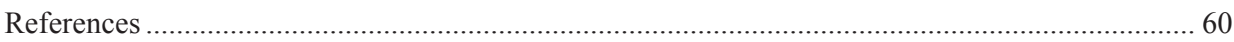


5. Going beyond the Rural Development Programme: a Master Plan for Austria's rural areas in the framework of the CAP

Dip.-Ing. Klaus Wagner

5.1. Introduction

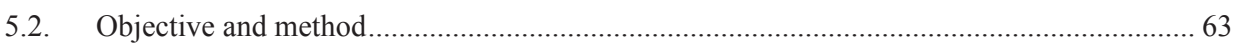

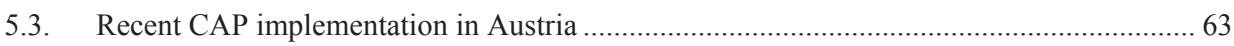

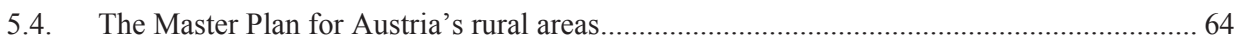

5.5. CAP in the system of the EU policy objectives and in the view of regional science

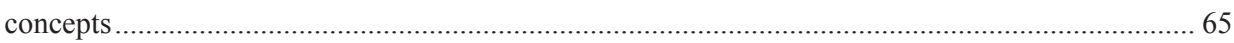

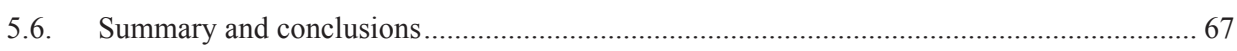

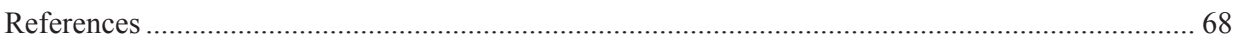

6. Possibilities to connect the Romanian agricultural research to the market requirements 69 Prof. Gabriel Popescu

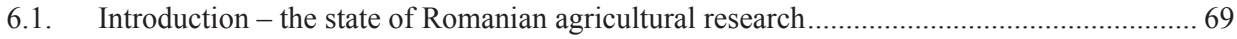

6.2. The problems faced by agricultural research since 1990 ..................................................... 71

6.3. Possible solutions for the recovery of Romanian agricultural research ................................ 76

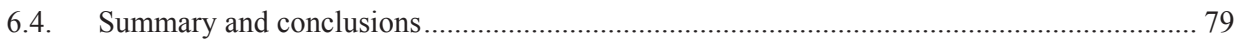

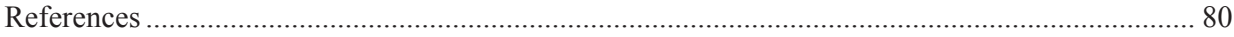

7. Price relationships of the production factors as exogenous determinants of production in agriculture.

Prof. dr hab. Włodzimierz Rembisz, PhD Adam Waszkowski

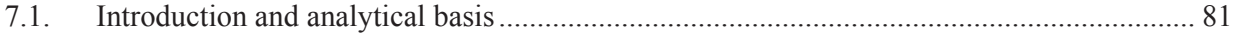

7.2. Relationships of prices of the capital, labour and land factors - hypothetical approach...... 83

7.3. Relationships of prices of the capital, labour and land factors - empirical approach .......... 84

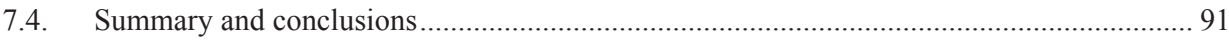

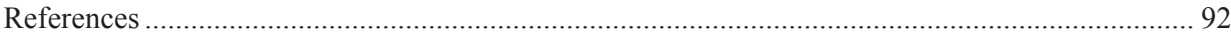

8. Effects of direct payments on agricultural development in Bulgaria ............................. 93 PhD Bozhidar Ivanov

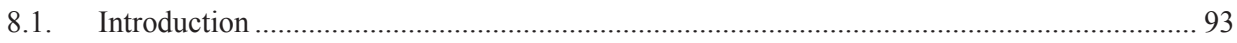

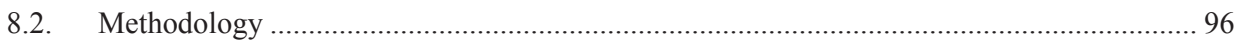

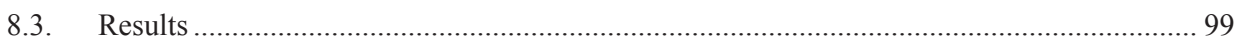

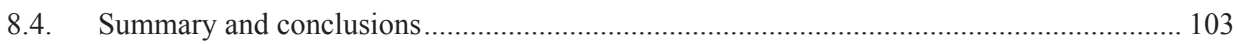

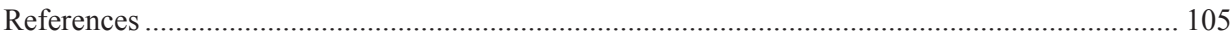

9. Re-adjusting risk management within the CAP: evidences on the implementation of the

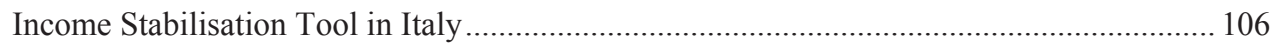
Prof. Samuele Trestini, PhD Elisa Giampietri

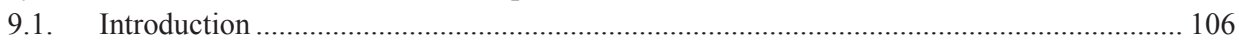

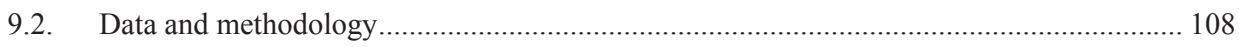




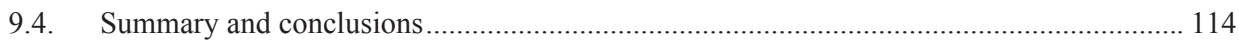

References

10. Comparison of risk management tools under the CAP of the EU, the US Farm Bill

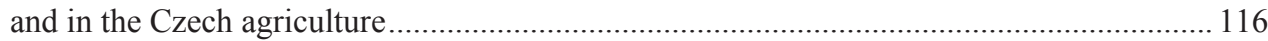
Ing. Václav Vilhelm, CSc., Ing. Sumudu Namali Gouri Boyinová, PhD Jindřich Špička

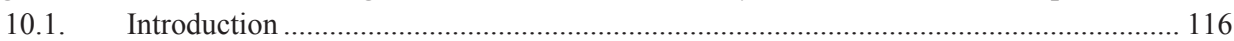

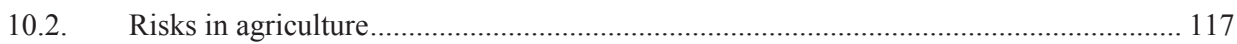

10.3. Risk management policy in the United States Farm Bill 2014 _..................................... 118

10.4. Risk management policy of the European Union's CAP ................................................ 119

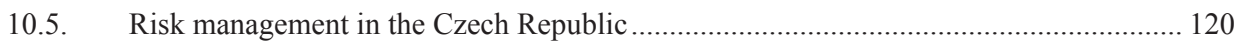

10.6. Comparative analysis of risk management policies ........................................................ 121

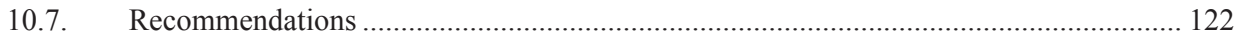

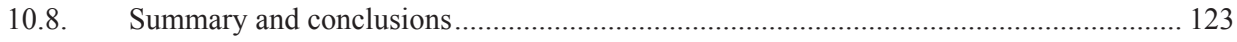

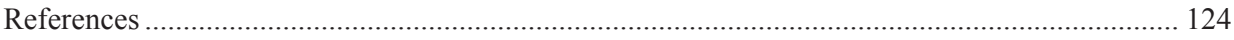

11. Factors determining the crop insurance level in Poland taking into account the level

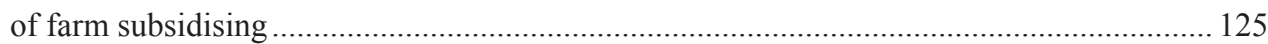

Prof. Adam Was, PhD Pawet Kobus

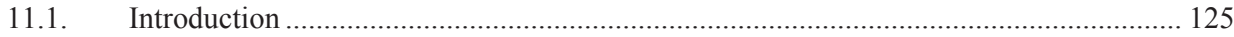

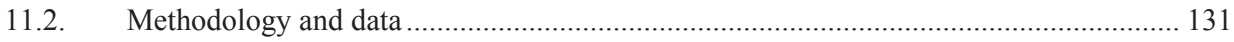

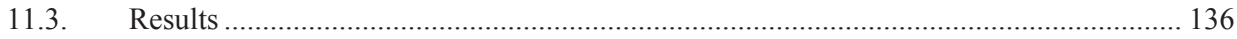

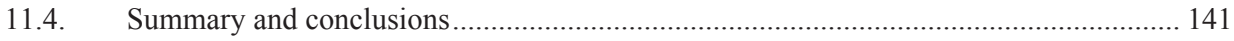

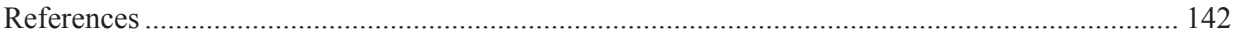

12. Farms and agricultural enterprises for development of sustainable and smart cooperatives: a multifactor approach using digital farm management ............................... 147 Prof. dr habil Adriana Mihnea, Prof. dr Dimitre Nikolov, dr Krasimir Kostenarov

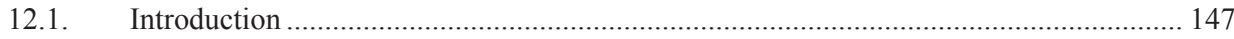

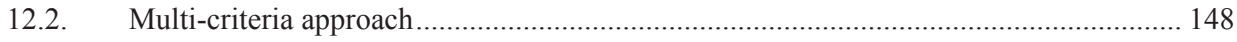

12.3. Construction of Farm Management Model ................................................................ 150

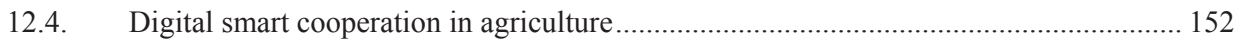

12.5. Application of the ANP Farm Management Model ....................................................... 154

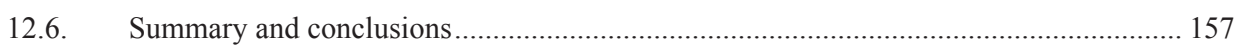

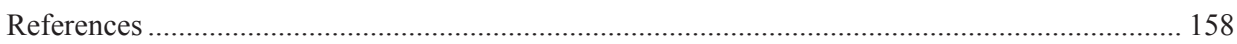

13. Brexit - potential implications for the Polish food sector .............................................. 159

Dr Katarzyna Kosior, Dr Łukasz Ambroziak

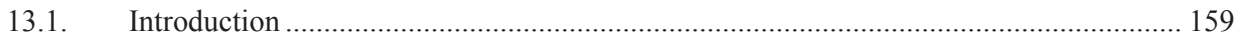

13.2. Negotiations on Brexit - what should be the model of the future relations? ..................... 161

13.3. The future of the EU finances and the CAP in the context of Brexit .............................. 163 
13.4. Impact of possible changes in the CAP budget on the net balance of Poland and transfers to the Polish agriculture.

13.5. The potential impact of Brexit on agri-food trade between Poland and the United

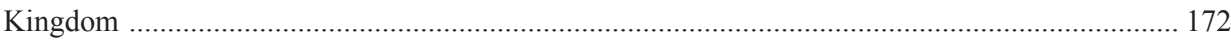

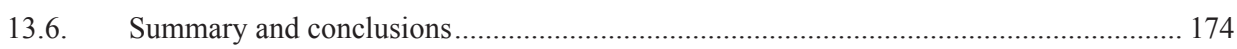

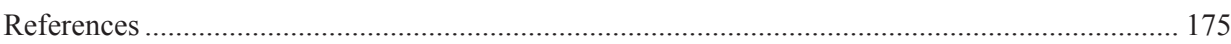

14. The Transatlantic Trade and Investment Partnership (TTIP): a threat or an opportunity for the EU-Mediterranean agriculture and agri-food sector? An exploratory survey ........... 177 Dipl.-Ing. Katja Pietrzyck, PhD Noureddin Driouech, Prof. Brigitte Petersen

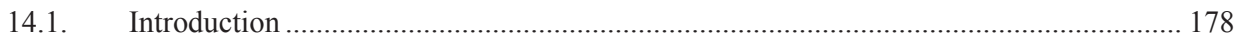

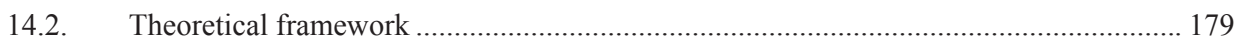

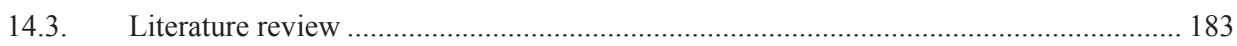

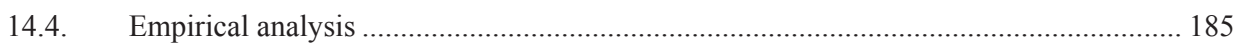

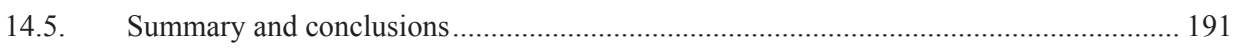

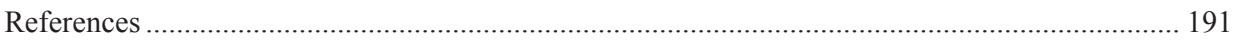

Appendix I: Overview of trade statistics regarding selected products ........................................... 195

15. The concept of short supply chains in the food economy............................................. 196

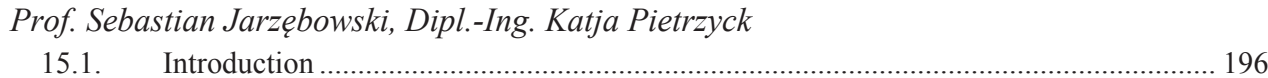

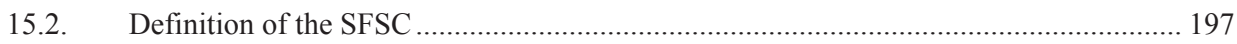

15.3. Development of short supply chains in Europe............................................................. 201

15.4. Global context of European short supply chains ........................................................... 205

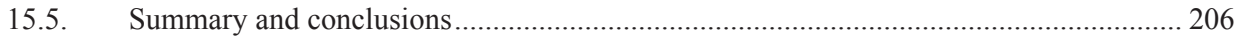

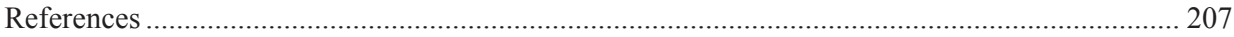

16. The CAP implementation in Wallonia - today performance and questions for the future -

A brief supplementary comment from Warmia and Mazury perspective............................. 209

PhD Philippe Burny, PhD Benon Gazinski

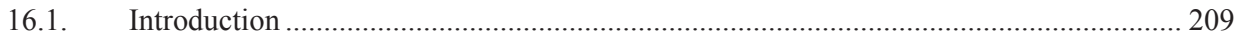

16.2. Implementation of the green payment in Wallonia in 2015 ........................................ 210

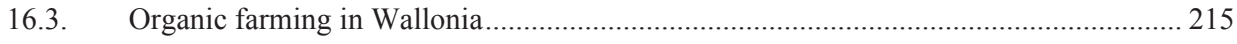

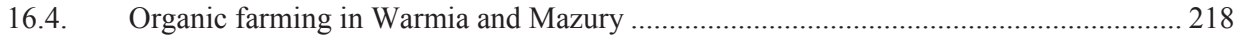

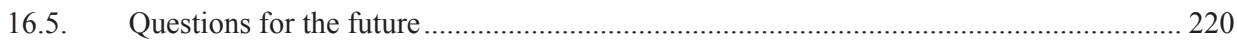

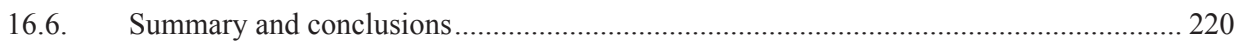

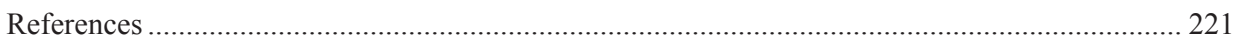

17. Afforestation of agricultural land financed from the RDP 2014-2020 ....................... 224

PhD Marek Zieliński

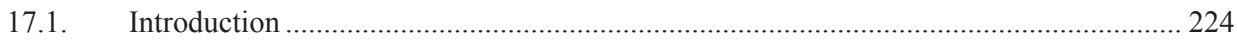

17.2. Natural farming conditions in Poland in regional terms................................................. 225 
17.3. The impact of natural farming conditions in Poland on the economic situation and the possibility of afforestation on farms

17.4. Land afforestation financed from the RDP 2014-2020 in regional terms

17.5. Importance of land afforestations financed under the RDP 2014-2020 in the EU climate policy for 2021-2030.

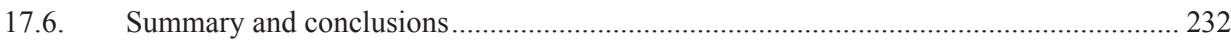

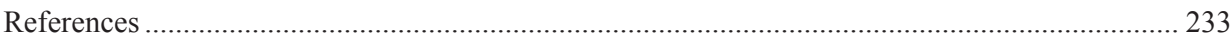

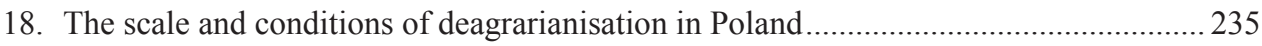

PhD Michat Dudek, PhD Bożena Karwat-Woźniak

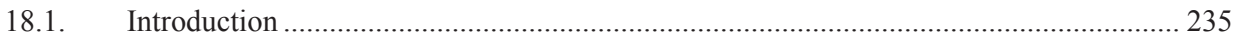

18.2. The conditions of the decrease in employment in agriculture ......................................... 236

18.3. The change in the scale of employment in agriculture in Poland and its conditions....... 238

18.4. The instruments of the Cohesion Policy and agriculture and rural development of the EU

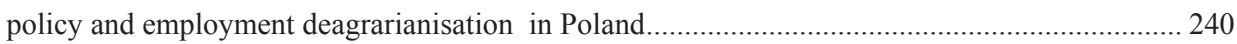

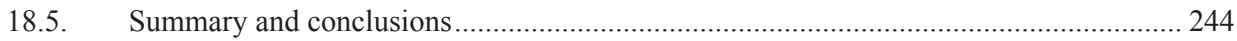

References 245

19. Socio-economic and environmental parameters and results of rural development under the CAP: the case of Bulgaria ................................................................................................ 247 Prof.dr.hab. Julia Doitchinova, Prof.dr.hab. Ivan Kanchev, Ass.Prof. Ralitsa Terziyska PhD, Ass.Prof. Kristina Todorova PhD

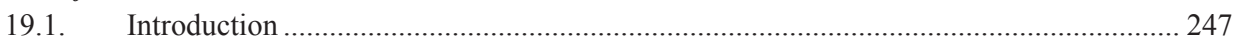

19.2. Changes in Bulgarian rural areas - socio-economic and environmental aspects................ 248

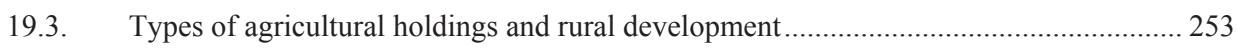

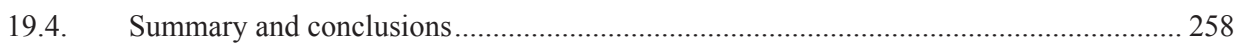

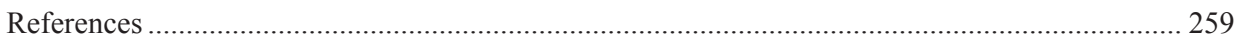

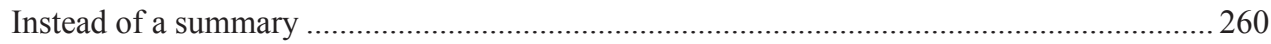

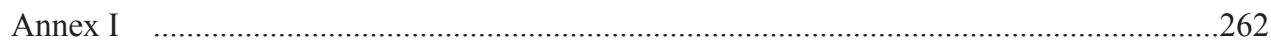




\title{
12. Farms and agricultural enterprises for development of sustainable and smart cooperatives: a multifactor approach using digital farm management
}

\author{
Prof. dr habil Adriana Mihnea ${ }^{1}$, Prof. dr Dimitre Nikolov ${ }^{2}$, \\ dr Krasimir Kostenarov ${ }^{3}$ \\ ${ }^{1}$ Bucharest University of Economic Studies, \\ ${ }^{2}$ Director of the Institute of Agricultural Economics, Sofia, \\ ${ }^{3}$ New Bulgarian University, Sofia
}

adriana.agapie@yahoo.com,dnik_sp@yahoo.com,kraskostenarov@yahoo.com

DOI: $10.30858 / \mathrm{pw} / 9788376587431.12$

\begin{abstract}
This paper presents a multi-criteria mathematical model which is capable to facilitate the formation of smart cooperatives and to collect behavioural data about small farmers. The model for smart cooperation is based on Gross Margin calculation and a multifactor approach known as the Analytic Network Process. The ANP, based on the farmer estimations, allows us to determine his behavioural risk for managing the farm. The model can also be useful for banks and insurance companies as they can be interested in estimating the risk for the farmers.
\end{abstract}

Keywords: smart cooperatives, risk profile, farm management model

JEL codes: Q12, D24, D81, Q13

\subsection{Introduction}

Smart cooperatives refer to the economic aspects of enforcing cooperation based on some common activities or objectives. The Third Green Revolution marks the path of digitization in otherwise traditional farming and the introduction of smart agriculture (smart farming technologies, SFTs). According to the European Innovation Partnership "Agricultural Productivity and Sustainability", $80 \%$ of the US farmers use some of these technologies in their production. The STFs are the key to precision farming, i.e. effective resource management in agriculture. Smart technologies are already incredibly diverse - from sensors to monitor the chemical composition of the soil to the use of drones to detect plant diseases, automated irrigation equipment, navigation systems for machinery, etc.

This paper presents a multi-criteria mathematical model, which is capable of facilitating the formation of smart cooperatives and collecting behavioural 
data about small farmers. The value of this behavioral, qualitative data is unique and can be valued in a large range of domains ${ }^{17}$.

Two of these domains regard the banks and insurance companies. The model can be useful for them by distinguishing the risk profile of the individual farmers. One of the major problems faced by funding organizations is to assess the behavioural risk of farmers. Using the multifactor model makes it possible to assess behavioural risk of farmers and to estimate the expected outcome of their activities.

Additionally, the agricultural and food sector need to change systemically. The data that is collected can make connections between farm modernization and rural development. We see the possibilities for, and drivers and limitations of sector change in four thematic areas: the resilience of farms and rural areas; prosperity and well-being; knowledge and innovation; and, the governance of agriculture and rural areas.

\subsection{Multi-criteria approach}

The Analytic Hierarchy Process and the Analytic Network Process are a part of multi-criteria approach as a decision making models constructed for synthesis of information. Their main benefits are when one have to solve problems that do not have clear quantitative measure, especially when the problem is related to social elements, subjective opinions, etc. Both the Analytic Hierarchy Process (AHP) and the Analytic Network Process (ANP) were introduced and their theoretical framwork was developed by T. Saaty [2001]. Historically and logically the AHP is the first model that appeared [Saaty, 1980]. The AHP can help with weighing of various alternatives according to a set of criteria, when the influences between alternatives and criteria are hieratical. At the top of the there hierarchy is the decision-making goal (Fig. 1).

The Analytic Network Process is a model that allows for considerably greater complexity. It recreates a system that allows dependences not only in the direction from a higher to a lower hierarchy toward the alternatives. When using the Analytic Network Process, it is possible that dependences are in both directions - from components to alternatives or from alternatives to the components. Additional dependences between components are possible. That creates a system that is much more complex and capable of describing in much more details the economic systems and dependences between different players on the market, etc. (Fig. 2)

\footnotetext{
${ }^{17}$ For processing the information a software named GoMo (www.GoMo.bg) was created. GoMo bases on several principles ofoperation: (1) it gathers the experience and support of Bulgarian farmers; (2) it uses knowledge in the field of economy; (3) it follows the achievements of the information society for the processing of information; (4) it creates a potential for new competitive business models based on shared data.
} 
Figure 1. Analytic Hierarchy Process

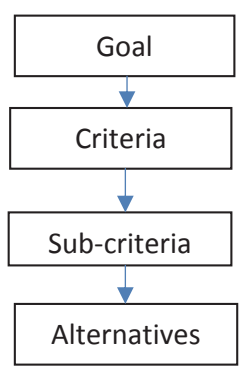

Source: own study.

Figure 2. Analytic Network Process

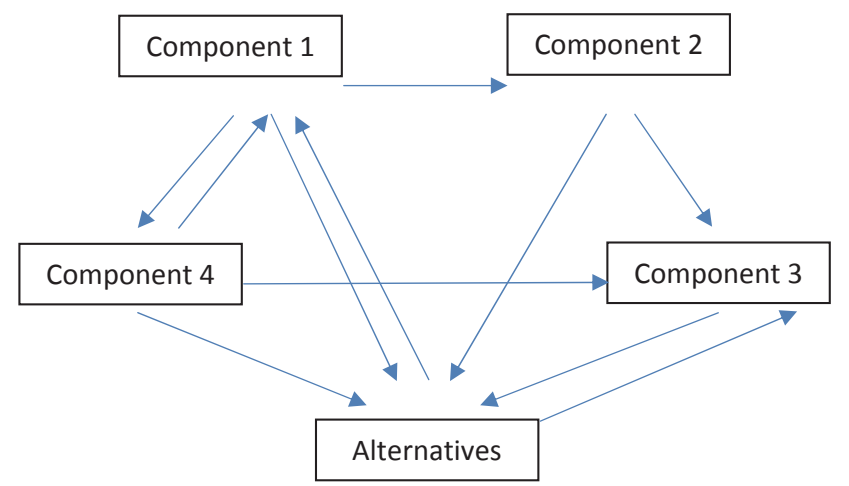

Source: own study.

In addition, the components may be constituted by elements. When evaluating the influence of components and elements on the alternatives, it is necessary to make pairwise comparisons between the individual elements. These comparisons are made on a scale from 1/9 to 9, where 1 means that both elements have equal influence on the alternatives, 9 means that the factor in the row has very strong influence and the factor in the column has no influence, 1/9 means that the factor in the column has very strong influence and the factor on the row has no influence. Table 1 summarizes possible scores and their explanation for the estimation of the elements.

Possible applications of the ANP can be very wide. It can be successfully used for solving decision problems in private corporations, public issues, military and conflict decisions, forecasting, market share estimation [Saaty and Vargas, 2006]. 
Table 1. The scale for estimation

\begin{tabular}{|l|l|l|}
\hline \multicolumn{1}{|c|}{ Numerical } & \multicolumn{1}{|c|}{$\begin{array}{c}\text { Intensity of } \\
\text { importance }\end{array}$} & \multicolumn{1}{|c|}{ Definition explanation } \\
\hline 1 & Equal importance & $\begin{array}{l}\text { Two activities contribute } \\
\text { equally to the objective }\end{array}$ \\
\hline 2 & Weak or slight & $\begin{array}{l}\text { Experience and judgement } \\
\text { slightly favour one activity } \\
\text { over another }\end{array}$ \\
\hline 4 & Moderate importance & Strong importance \\
\hline 5 & $\begin{array}{l}\text { Experience and judgement } \\
\text { trongly favour one activity } \\
\text { over another }\end{array}$ \\
\hline 6 & Strong plus & $\begin{array}{l}\text { An activity is favoured very } \\
\text { strongly over another; its } \\
\text { dominance demonstrated in } \\
\text { practice }\end{array}$ \\
\hline 7 & Very strong or demonstrate \\
\hline 8 & importance & $\begin{array}{l}\text { The evidence favouring one } \\
\text { activity over another is of } \\
\text { the highest possible order of } \\
\text { affirmation }\end{array}$ \\
\hline 9 & Very, very strong &
\end{tabular}

Source: Saaty and Vargas [2006].

\subsection{Construction of Farm Management Model}

The design of targeted, well-tailored policies in the agriculture, articulated with the CAP, is flawed by the particularities of small farms, their main concern being the amount of the allocated subsidies. Inability to form associative structures like, for example, agricultural cooperatives, based on common activities is usually blamed on the historical past when such solutions were enforced against the will of the proprietors. Nowadays, general discussions about the optimal functioning of the cooperatives in agriculture are carried out, with the scope to improve efficiency and achieve economies of scale.

Scopes and reasoning of the small farmers differ from behavioural perspective from those of large farms. In the process of production, substitutability between factors of production depends on many issues. We can stress the following behavioural patterns:

- The vulnerability to the weather conditions and farmers reaction to it; 
- The simple ignorance about specific solutions;

- The ignorance of the official recommendations about specific conditions.

Risks and expectations mutually reinforce in the attempt to improve the farm operational management. In predicting and planning production, price and income for agricultural farms, both a priori and a posteriori Gross Margin's (GM) computation operates as proxy for the profit's dynamics. The correct estimation of the gross margin can act as a proxy for the dynamics of future profits.

This is why, the existence of a reliable, real data base concerning behavioural data presenting the process of formation of expectations regarding the current and future gross margin, stay at the base of the success of any action on the small farms. The model proposed is built on an innovatory mathematical model, following a multi-criteria approach.

The model constructed using this technique is entirely original and it was tailored to the specific needs of the Bulgarian agriculture. Several focus groups helped to construct, confirm and estimate this prototype and specific derivations, like the estimation of the cash flow, break-even point or the risk profile of the users.

The software allows farmers to be more and more conscious about:

- the structure of the variable costs,

- the errors in the estimation of gross margin,

- better adjusting their expectations and also the options they have about costs,

- the degree of substitution between factors of production.

Perhaps one of the most important other achievements is the possibility to aggregate these behavioural data on reports to be used as meaningful references of performance comparisons and to assist in the design of optimal agricultural policies.

The model is build using the Analytic Network Process (ANP) theory to incorporate behavioural decisions at the level of small farms regarding the substitution in between factors of production with the aim of determining the expected gross margin (GM).

- It is anchored on a standard calculation of the GM;

- The calculation of the GM follows the next theoretical idea:

- Consider there is a farmer's production function:

(1) $Y=Y(L a b o u r$, Nutrition, Chemicals, Canopy , Machinery, Irrigation...), where:

$\mathrm{Y}$ is the yield and Labour, Nutrition, Chemicals, Canopy, Machinery, Irrigation are all factors of production. 
Gross Margin (GM) can be regarded as a proxy for the dynamics of the profits, being calculated as:

(2) $\mathrm{GM}=\mathrm{Y}^{*}$ Average Gross price-Variable Costs, where:

(3) Variable Costs $=\mathrm{wL}^{*}$ Labour* ${ }_{\mathrm{w}} \mathrm{w} *$ Nutrition $*+\ldots . . \mathrm{WI} *$ Irrigation $*+\ldots$.

Where Labour*, Nutrition*, Irrigation* and so on represent the optimal demand functions for the correspondent input factors of production after minimizing the cost of producing an arbitrary level of output $Y$.

It is customary to place the issue of determining the gross margin under the theoretical assumption of separability of the factors of production, yet this hypothesis is mostly contradicted for small farms.

This fact leads to significant discrepancies between the theoretical-standard estimations of the GM and the actual ones, these discrepancies being further interpreted as departures from some efficiency and optimal and standard values. These departures impede further derivations like a correct determination of future cash flows, break-even point and future profits and through that, conduce to an improper estimation of the farmers risk profile and management efficiency and, thus, to an inadequate financing of the specific agricultural activities.

To sum up, the main two theoretical assumptions in the neo-clasicall theory of production function are:

- the separability of the factors of production; and

- the dependence between the output and the selling price in the context of market characterization are addressed by this model and replaced by the next two assumptions.

The interdependence (substitutability) of the factors of production in case of small farms, is inversely proportional with the size of the farm.

The construction of the cluster matrix assessing the comparative importance of all the variables participating in the formation of the GM address exactly the two theoretical drawbacks previously mentioned.

\subsection{Digital smart cooperation in agriculture}

The core of the model for smart cooperation is the Gross Margin. It can be used as a proxy for profits, break-even analysis, cash flow, trends in development and investment. Many influence factors and dependences can be built around the Gross Margin, including input factors in agriculture, trading platform for nutrients, chemicals, machinery, financing instruments, consumers, reports, databases created from various dates (Table 2). 
Table 2. Digital Smart Cooperation in Agriculture: Gross Margin and area of dependences.

\begin{tabular}{|c|c|c|}
\hline External users & Digital solution & Internal benefits \\
\hline Input factors in agriculture & $\begin{array}{l}\text { A platform for comer- } \\
\text { cialization of various } \\
\text { nutrients, chemicals, } \\
\text { machinery }\end{array}$ & Behavioural database \\
\hline $\begin{array}{l}\text { Producers of fertilizers, chemi- } \\
\text { cals, nutrients, seeds, machinery }\end{array}$ & $\begin{array}{l}\text { To be used as a the start- } \\
\text { ing point in the future } \\
\text { diversification and refin- } \\
\text { ment in the production } \\
\text { process }\end{array}$ & $\begin{array}{l}\text { About expectation for- } \\
\text { mation in the production } \\
\text { and distribution for small } \\
\text { and medium farm producers }\end{array}$ \\
\hline Financing instruments & $\begin{array}{l}\text { Gross Margin for smalll } \\
\text { and medium farms }\end{array}$ & A bold database \\
\hline $\begin{array}{l}\text { Banks, insurance companies, } \\
\text { credit cooperatives }\end{array}$ & $\begin{array}{l}\text { As a proxy for profits, } \\
\text { break-even point, cash } \\
\text { flow, trends in develop- } \\
\text { ment and investment }\end{array}$ & $\begin{array}{l}\text { About assets, input factors } \\
\text { demand and nominal pro- } \\
\text { duction - leading to a more } \\
\text { accurate assesment of fi- } \\
\text { nancial reliabaility of indi- } \\
\text { vidual farmers }\end{array}$ \\
\hline Consumers & $\begin{array}{l}\text { A platform for traiding } \\
\text { of production inputs and } \\
\text { outputs }\end{array}$ & $\begin{array}{l}\text { Reports on agregated per- } \\
\text { formances }\end{array}$ \\
\hline $\begin{array}{l}\text { Individuals, processing and/or } \\
\text { storage }\end{array}$ & $\begin{array}{l}\text { To be used as a starting } \\
\text { point in the future for } \\
\text { smart cooperation and } \\
\text { other trding busineses }\end{array}$ & $\begin{array}{l}\text { For a correct distinction in } \\
\text { between categories of farm- } \\
\text { ers, crops, regions etc. }\end{array}$ \\
\hline
\end{tabular}

Source: own study.

Once the data is digitalized it can be used in many different ways. One of the most valuable application can be simulating different scenarios based on assumptions and alternatives. These simulations can be loaded with different behavioural data for farmers. The software can show various correlations on individual level or at the level of the market as a whole. It will be possible to create risk profile on a number of trials and consistency index. "What if" scenarios will be easily accessible for the farmers and they will be able to study different options (Figure 3). 
Figure 3. Smart cooperation in agriculture - possible outcome and benefits

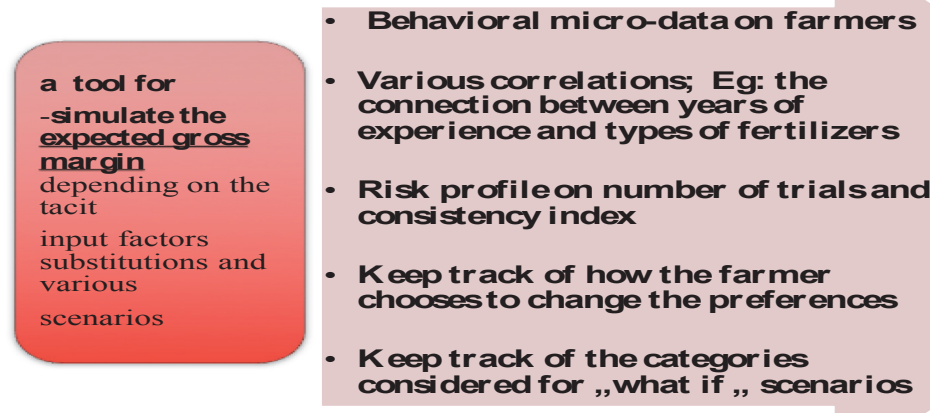

Source: own study.

\subsection{Application of the ANP Farm Management Model}

The ANP can be used as a management tool on farms. To demonstrate how it can be useful we are going to use a honeybee farm as an example. The first that is important is the farmer to decide what are the alternatives. Our proposal is that alternatives can be:

- Nominal Gross Margin - that is the GM calculated form the farmer based on his real results;

- Pessimistic Gross Margin - that is the GM calculated from nominal GM certain $\%$ of the GM (the \% is defined by the farmer);

- Optimistic GM - that is the GM calculated from nominal GM + certain \% of the GM.

The second step is to arrange the components (sometimes called clusters) of dependencies and the elements of the components. After a consultation with honeybee farmers we have defined the following components: income, food, consumables, medicines, work, others. The clusters and their dependences are shown in Figure 4. As it is shown, the alternatives depends on all clusters but also the clusters depend on the alternatives. One can observe that from the arrows. If the arrow points in both directions that means that cluster influences the alternatives and the alternative influences the cluster too. In our particular case if we take for example the food cluster. It is obvious that the quality and quantity of food can influence the alternatives (i.e. Gross Margin). From other point of view, if the farmer requires higher Gross Margin he should be aware of the 
quantity and quality of food needed and he should distribute enough food to the bees. That is how the influence can go from clusters to the alternatives and back.

Moreover, the observations clearly showedthat there are not only dependences between alternatives and clusters but also between clusters too. In Figure 4, they are shown as arrows between clusters. The direction of the arrows shows the direction of dependence. If it is in one direction the dependence goes form one cluster to the other. If the arrow is in both directions then the dependence goes form one cluster to the other but the other influences the first too.

Figure 4. Clusters and dependences of a honeybee farm

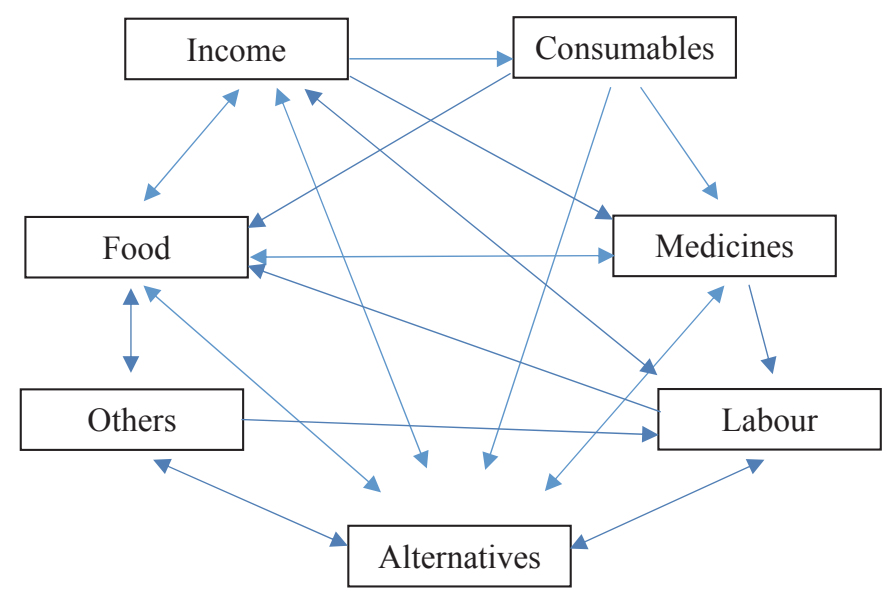

Source: own study.

The next step is to define the elements of clusters. They are summarized in Table 3.

Table 3. Elements of the components (clusters)

\begin{tabular}{|l|l|l|l|l|l|}
\hline Income & Food & Consumables & Medicines & Labour & Others \\
\hline Direct sales & Sugar & Wax bases & Regular & Farmer & Transport \\
\hline Retailers & Honey & Frames & Not regular & Family & Certification \\
\hline Subsidies & $\begin{array}{l}\text { Prepared } \\
\text { food }\end{array}$ & & $\begin{array}{l}\text { Seasonal } \\
\text { work }\end{array}$ & \\
\hline
\end{tabular}

Source: own study.

Every element in any cluster can influence any other element in all clusters. The influence of the elements over the other elements of the network can be represented by a matrix, which is known as a supermatrix. The supermatrix of a honeybee farm is represented in Table 4 . Not all cells of the supermatrix have 
to be filled in with estimations. We have to create only the matrixes of dependences between clusters and elements that we find an influence. These are the same influences that we have outlined in Figure 4.

There is a problem of a practical nature here. Each arrow, which is seen in Figure 4, must be evaluated with a series of matrixes. If the arrow is in both directions - the number of matrices is doubled. The number of matrixes depends on the number of elements in the clusters. Additionally each matrix consists of multiple estimations. For example if we evaluate the matrix of the dependences between income and food clusters we will have 6 different matrixes to evaluate. Each matrix consist of 3 independent estimations. As you can imagine the number of evaluations grows exponentially with the numbers of clusters and dependences between them. In our case this means that 55 matrixes should be created, every matrix with a number of estimations (Table 4). Our opinion is that in practice the farmers will not make so much estimations or will make estimation automatically which can make the estimation invalid.

Table 4. Visualization of cluster matrix

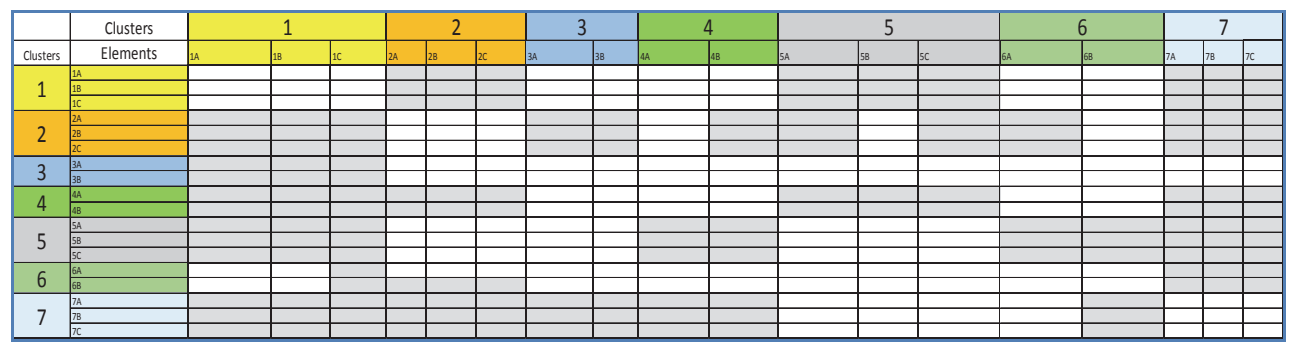

* The colored leading rows and columns represent different clusters and elements. The gray area inside are the matrixes that have to be estimated.

Source: own study.

Cluster numbers are: 1 - Income; 2 - Food; 3 - Consumables; 4 - Medicines; 5 -Work; 6 - Others; 7 - Alternatives. Element numbers are: 1A - Direct sales; 1B - Retailers; 1C - Subsidies; 2A - Sugar; 2B - Honey; 2C - Prepared food; 3A - Wax bases; 3B - Frames; 4A - Regular; 4B - Not regular; 5A Farmer; 5B - Family; 5C - Seasonal work; 6A - Transport; 6B - Certification; $7 \mathrm{~A}-\mathrm{GM}-10 \%$; 7B - GM; 7C - GM +10\%.

In order to solve this problem, we decided to further assess the dependencies between clusters and classify them as strong and weak dependencies. Subsequently, we removed the weak dependencies from the supermatrix and thus reduced the number of matrices to 15 (Table 5). 
Table 5. The reduced number of dependences between clusters and elements.

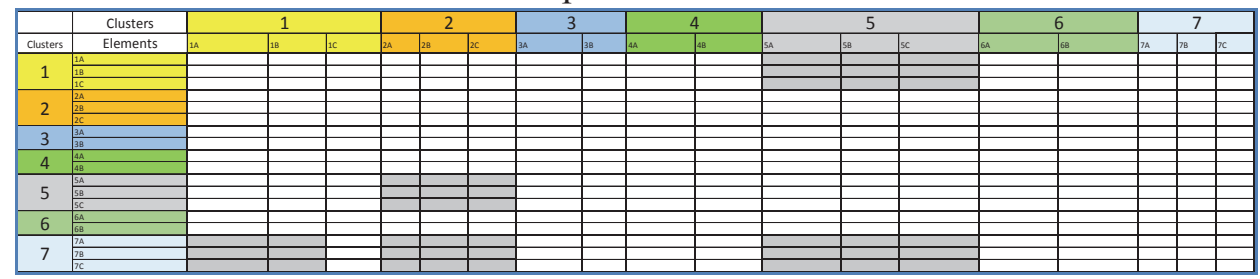

Source: own study.

If the supermatrix is solved in this way, that means all clusters have an equal weight. It is logical to assume that clusters have a different weight in the final evaluation of alternatives. Therefore, a cluster matrix is created that assesses the degree of impact of individual clusters. The cluster matrix is assessed by experts and is not set by the farmers. The cluster matrix for honeybee farm is shown on table 6.

Table 6. Cluster matrix of a honeybee farm.

\begin{tabular}{|l|r|r|r|r|r|r|r|}
\hline & Income & Food & Consumables & Medicines & Work & Others & Alternatives \\
\hline Income & $25 \%$ & $23 \%$ & $22 \%$ & $18 \%$ & $30 \%$ & $23 \%$ & $33 \%$ \\
\hline Food & $16 \%$ & $21 \%$ & $28 \%$ & $28 \%$ & $16 \%$ & $12 \%$ & $27 \%$ \\
\hline Consumables & $3 \%$ & $4 \%$ & $8 \%$ & $7 \%$ & $4 \%$ & $7 \%$ & $5 \%$ \\
\hline Medicines & $7 \%$ & $9 \%$ & $4 \%$ & $10 \%$ & $5 \%$ & $9 \%$ & $5 \%$ \\
\hline Work & $22 \%$ & $7 \%$ & $12 \%$ & $5 \%$ & $23 \%$ & $16 \%$ & $19 \%$ \\
\hline Others & $2 \%$ & $4 \%$ & $4 \%$ & $6 \%$ & $3 \%$ & $7 \%$ & $3 \%$ \\
\hline Alternatives & $24 \%$ & $31 \%$ & $22 \%$ & $26 \%$ & $19 \%$ & $26 \%$ & $8 \%$ \\
\hline
\end{tabular}

Source: own study.

After calculating the cluster matrix, the initial supermatrix is weighted with the farmer's estimates and the final weights of the alternatives are calculated.

\subsection{Summary and conclusions}

The result of the analysis shows comparatively equalized probabilities for each of the alternatives ranging around 30\% (have in mind that the result is from the answers of our experts, which is why we find it as expected). A slightly higher probability is for the pessimistic option $-39 \%$.

Table 7. Weights of the alternatives according the ANP

Source: own study.

\begin{tabular}{|l|r|}
\hline Pessimistic GM $-10 \%$ & $39 \%$ \\
\hline Nominal GM & $27 \%$ \\
\hline Optimistic GM $+10 \%$ & $34 \%$ \\
\hline
\end{tabular}


As a summary of the results it can be said that if moderate results are shown, as in the example shown, this indicates that the behavioural risk of the farmer is minimal. It can be assumed that he follows a coherent technology tailored to the specifics of production. Large percentages for one of the variants would be indicative of a specific behavioural risk and could alert the interested party. The application of the ANP to a large group of farmers can achieve even better results by comparing them on a regional basis or over different periods of time.

\section{References}

1. Saaty, T.L. (1980). The Analytic Hierarchy Process. McGraw-Hill: New York.

2. Saaty, T.L. (2001). The Analytic Network Process. RWS Publications: Pittsburgh, PA.

3. Saaty, T.L. (2008). Decision making with Analytic Hierarchy Process. Int. J. Services Sciences, Vol. 1, No. 1, 2008.

4. Saaty, T., Vargas, L. (2006). Decision Making With the Analytic Network Process: Economic, Political, Social and Technological Applications with Benefits, Opportunities, Costs and Risks, Springer. 